\title{
Oestrogen production by blastocyst and early embryonic tissue of various species
}

\author{
J. E. Gadsby*, R. B. Heap and R. D. Burton \\ A.R.C. Institute of Animal Physiology, Babraham, Cambridge CB2 4AT, U.K.
}

\begin{abstract}
Summary. Oestrogen synthesis by the early embryo in vitro was studied with tissue from pigs, sheep, cows, roe deer, ferrets, cats, rabbits and a plains viscacha. Definitive evidence for aromatase activity and oestrogen synthesis in preimplantation trophoblast was obtained for the pig with the formation of oestrone, oestradiol-17 $\beta$ and oestradiol-17 $\alpha$ from ${ }^{3} \mathrm{H}$-labelled androstenedione and dehydroepiandrosterone. Aromatase activity was appreciably lower in all other species studied, and labelled oestrogens were recovered only from incubations of allantochorionic tissue of roe deer, recovered shortly after implantation, and from pooled samples of early embryonic tissue of cows. High aromatase activity in preimplantation trophoblast of pigs was associated with the maternal recognition of pregnancy and the occurrence of superficial implantation in this species.
\end{abstract}

\section{Introduction}

In previous studies we reported biochemical evidence for the presence of aromatase in pig blastocysts (Perry, Heap \& Amoroso, 1973; Perry, Heap, Burton \& Gadsby, 1976; Flint, Burton, Gadsby, Saunders \& Heap, 1979). Other enzymes of the steroid synthetic chain are also present in preimplantation pig embryos, and oestrogens are formed from pregnenolone and progesterone in vitro provided co-factors are added to the incubation medium (Gadsby, Burton, 'Heap \& Perry, 1976). Further work has shown that aromatase is detectable by the time of maternal recognition of pregnancy (Flint et al., 1979), an event that begins on about Day 12 post coitum (p.c.) (Dhindsa \& Dziuk, 1968), and it has been suggested that oestrogens of trophoblast origin may be the embryonic signal which initiates this event (Flint et al., 1979). In addition, trophoblast oestrogens have been implicated in the process of implantation since in certain animals implantation occurs after ovariectomy when the operation is performed in early pregnancy and progesterone alone is administered (Dickmann, Dey \& Sen Gupta, 1976). Pigs, sheep and rabbits are animals in this category and they differ therefore from murine rodents in which implantation does not occur in the absence of ovarian oestrogen secretion (Singh \& Booth, 1979). We have investigated the occurrence of trophoblast aromatase and other steroid metabolizing enzymes at about the time of implantation in various animals to elucidate possible physiological roles of blastocyst oestrogens in the maternal recognition of pregnancy and implantation.

* Present address: Reproductive Endocrinology Program, Department of Pathology, University of Michigan, Ann Arbor, Michigan 48109, U.S.A. 


\section{Materials and Methods}

\section{Animals}

Material was obtained from pregnant animals of known gestational stages. Pigs were obtained from the Institute's herd of Large White and Landrace sows; sheep were from the Institute's flock of Clun Forest ewes; and cows were from this Institute (Animal Research Station, Huntingdon Road, Cambridge), and the A.R.C. Institute for Research in Animal Diseases, Newbury. New Zealand White rabbits were obtained from the Institute's colony, and cats, ferrets (Mustela putorius) and a plains viscacha (Lagostomus maximus) were supplied by the Royal Veterinary College, London, and the Departments of Applied Biology and Anatomy, University of Cambridge. The reproductive tract was removed at autopsy, placed on ice and within $15 \mathrm{~min}$ of removal the blastocysts were flushed out by a sterile technique using Brinster's medium (Brinster, 1965) supplemented with sodium lactate $(21.58 \mathrm{mmol} / \mathrm{l})$, or with medium 199 (M199, Flow Laboratories, Irvine, or Gibco-Biocult Ltd, Paisley). The flushings were centrifuged at $600 \mathrm{~g}$ for $15 \mathrm{~min}$ and the residue was minced with fine scissors. When implantation had already occurred, embryonic tissue was separated from maternal tissue by fine dissection, or, in cats and ferrets, the implantation site was minced without further separation.

The tissues used in this study consisted of intact blastocysts from rabbits, cats, and a plains viscacha; elongated (or filamentous; classification of Anderson, 1978) blastocysts after removal of the embryonic region by fine dissection from pigs; elongated blastocysts from sheep and cows; and the chorionic sac and allantochorionic membrane from cows and roe deer (Capreolus capreolus).

\section{Incubation}

Minced tissue (about $300 \mathrm{mg}$ wet weight unless otherwise stated) was incubated in a shaking waterbath at $37^{\circ} \mathrm{C}$ for $3 \mathrm{~h}$ and gassed with $5 \% \mathrm{CO}_{2}$ in $\mathrm{O}_{2}$. The incubation medium was $5 \mathrm{ml}$ M199 containing a known amount $(3.7-370 \mathrm{kBq})$ of labelled steroid which had been checked for purity by thin-layer chromatography. The specific activities $(\mathrm{TBq} / \mathrm{mmol})$ of the labelled steroids obtained from The Radiochemical Centre, Amersham, were: $\left[1,2-{ }^{3} \mathrm{H}\right]$ androstenedione, $1.69 ;\left[7 \alpha-{ }^{3} \mathrm{H}\right]$ dehydroepiandrosterone (DHA), $0.41 ;\left[1,2,6,7-{ }^{3} \mathrm{H}\right]$ testosterone, $3 \cdot 21 ;[6,7-$ ${ }^{3} \mathrm{H}$ ]oestrone, $1.70 ;\left[4-{ }^{14} \mathrm{C}\right]$ oestrone, $2.14 \mathrm{GBq} / \mathrm{mmol}$; and $\left[4-{ }^{-14} \mathrm{C}\right.$ )oestradiol-17\%, $2.07 \mathrm{GBq} /$ mmol.

\section{Extraction and purification of labelled steroids}

All solvents were A.R. grade and were used without redistillation. Incubated media (with tissue) were extracted twice with $10 \mathrm{ml}$ diethyl ether after the addition of ${ }^{14} \mathrm{C}$-labelled oestrone and oestradiol- $17 \beta$ to correct for procedural losses (approximately $0.25 \mathrm{kBq}$, sp. act. 518 $\mathrm{kBq} / \mathrm{mmol}$ ). The ether extract containing unconjugated steroids was decanted and evaporated to dryness under nitrogen. Extracts were dissolved in $10 \mathrm{ml}$ chloroform : carbon tetrachloride $(1: 5$, $\mathrm{v} / \mathrm{v})$ and $10 \mathrm{ml} 1 \mathrm{M}-\mathrm{NaOH}$ were added. Phenolic compounds were recovered from the separated $\mathrm{NaOH}$ fraction, neutralized with $0.75 \mathrm{ml} 18 \mathrm{M}-\mathrm{H}_{2} \mathrm{SO}_{4}$ and extracted with $20 \mathrm{ml}$ diethyl ether. The ether extract was washed with $5 \mathrm{ml} \%(\mathrm{w} / \mathrm{v}) \mathrm{NaHCO}_{3}$ and twice with $5 \mathrm{ml}$ distilled water, evaporated to dryness and dissolved in $1 \mathrm{ml}$ ethanol (phenolic steroid fraction, e.g. oestrogens). The chloroform: carbon tetrachloride fraction was washed with water (at least 3 times with $5 \mathrm{ml}$ distilled water), evaporated to dryness and dissolved in $1 \mathrm{ml}$ ethanol (neutral steroid fraction, e.g. androstenedione, DHA, testosterone). The aqueous fraction containing conjugated steroids was evaporated to dryness by a stream of air at $60^{\circ} \mathrm{C}$ and homogenized in $5 \mathrm{ml}$ distilled water at $4^{\circ} \mathrm{C}$ (aqueous fraction, e.g. steroid conjugates, sulphates and glucuronides). Radioactivity was determined in a one-tenth aliquot taken from each fraction by using a liquid scintillation spectrometer. 
Unconjugated oestrogens (oestrone, oestradiol-17 $\beta$ and oestradiol-17 $\alpha$ ) and neutral steroid metabolites were separated by thin-layer chromatography on silica gel $60 \mathrm{~F}_{254}$ (Merck, Darmstadt) by using the technique described by Challis, Harrison \& Heap (1973). Chromatograms were developed in the solvent system, cyclohexane :ethyl acetate $(11: 9$ or $1: 1, \mathrm{v} / \mathrm{v})$ or benzene : methanol $(9: 1, \mathrm{v} / \mathrm{v})$. After steroids were eluted, aliquots were counted. Oestrogens were characterized by recrystallization to constant specific radioactivity, or by the formation of derivatives (oestrone 3-monoacetate and oestradiol-3,17-diacetate) followed by re-chromatography. The techniques of acetylation, hydrolysis, chromatography and counting of radioactivity have been described elsewhere (Challis et al., 1973; Ricketts et al., 1980).

Values were corrected for procedural losses and expressed as the percentage of labelled precursor incorporated into phenolic and aqueous fractions, and into chromatographically separated oestrone and oestradiol-17\%.

\section{Results}

\section{Aromatizing system}

Pig. Aromatase activity was prominent in the preimplantation trophoblast of the pig (Table 1). The conversion of androstenedione to phenolic compounds, oestrone and oestradiol- $17 \beta$ was significantly higher in the presence of trophoblast than in control flasks without tissue $(P<$ $0 \cdot 01$ ). Incubations of tissue taken between Days 14 and 18 post coitum (p.c.) showed a high conversion of androstenedione, DHA and testosterone to oestrone and oestradiol-17 $\beta$. These oestrogens accounted for about two-thirds of the total radioactivity recovered in a phenolic fraction from incubations of trophoblast with androstenedione, DHA and testosterone $(67,60$ and $64 \%$, respectively). Other oestrogens formed from androstenedione included oestradiol-17a and a more polar oestrogen. Oestrone, oestradiol-17 $\beta$ and oestradiol- $17 \alpha$ were identified by recrystallization to constant specific radioactivity. The amount of precursor converted into phenolic steroids was greater with DHA than androstenedione although the difference was significant only in the amount of oestrone formed (Table 1). Oestrogen metabolism by 16-day trophoblast was demonstrated when labelled oestrone was used as substrate. Oestrone was converted to other oestrogens including oestradiol- $17 \beta(12.9 \pm 3.7 \%, 3$ experiments $)$ and a polar oestrogen with a chromatographic mobility similar to that of oestriol $(16 \cdot 1,29 \cdot 6 \%$, Textfig. 1a).

Ruminants. In ewes and cows there was a low conversion of androstenedione to phenolic steroids by trophoblast tissue. The conversion to phenolic compounds, oestrone and oestradiol-17 $\beta$ was not significant when compared with results obtained from control incubations. When oestrone and oestradiol- $17 \beta$ fractions from experiments on 6 sheep were combined and recrystallized 4 times, little or no radioactivity co-crystallized with authentic unlabelled oestrone and oestradiol-17 $\beta$ and the activity found in the mother liquor was gradually depleted with successive crystallization. However, combined fractions obtained from 7 cows (Table 1) resulted in the definitive identification of oestrone and oestradiol-17 $\beta$, the specific activity of the mother liquor reaching values similar to those of crystals after the third crystallization. The percentage of precursor associated with oestrone and oestradiol-17 $\beta$ after crystallization was 0.6 and $0.2 \%$, respectively.

Four blastocysts recovered from 2 roe deer during late diapause (early January) failed to metabolize labelled androstenedione, but after blastocyst activation and attachment aromatase was detected in allantochorionic tissue (Table 1). Definitive evidence was obtained for the synthesis of oestrone from labelled androstenedione.

Other species. A very low level of aromatase was found in tissue from ferrets, cats and rabbits, and from a plains viscacha which provided a large number of blastocysts $(>100)$. The precursor, DHA, was used in these studies because of the higher percentage conversion observed 
in the pig. The value for ferret, rabbit and plains viscacha tissue did not exceed one standard deviation above the mean value obtained in control incubations, but significant activity was detectable in the implantation sites of 2 cats immediately after implantation (Table 1).

Table 1. Oestrogen synthesis by blastocysts, trophoblast and early embryonic tissue about the time of implantation in various animals

\begin{tabular}{|c|c|c|c|c|c|c|c|c|}
\hline \multirow[b]{2}{*}{ Species } & \multirow[b]{2}{*}{$\begin{array}{l}\text { No. of } \\
\text { animals }\end{array}$} & \multirow{2}{*}{$\begin{array}{c}\text { Days } \\
\text { pregnant } \\
\text { p.c. }\end{array}$} & \multirow[b]{2}{*}{ Tissue ${ }^{* *}$} & \multirow[b]{2}{*}{ Precursor } & \multicolumn{4}{|c|}{$\%$ initial radioactivity associated with: } \\
\hline & & & & & $\begin{array}{l}\text { Phenolic } \\
\text { fraction }\end{array}$ & Oestrone & $\begin{array}{c}\text { Oestradiol } \\
-17 \beta\end{array}$ & $\begin{array}{l}\text { Aqueous } \\
\text { fraction }\end{array}$ \\
\hline $\begin{array}{l}\text { Control (no tissue; } \\
\text { mean } \pm \text { s.d.) }\end{array}$ & $5 \dagger$ & - & None & A, DHA & $1.6 \pm 1.4$ & $0 \cdot 1 \pm 0.1$ & $0.2 \pm 0.1$ & $0.9 \pm 0.4$ \\
\hline Pig & $\begin{array}{r}7 \\
10 \\
2\end{array}$ & $\begin{array}{l}14-18 \\
14-18 \\
15-16\end{array}$ & $\begin{array}{l}\text { FT } \\
\text { FT } \\
\text { FT }\end{array}$ & $\underset{\mathrm{T}}{\mathrm{A}}$ & $\begin{array}{l}21.2 \pm 3.0 \\
36.9 \pm 6.8 \\
11.8,36.7\end{array}$ & $\begin{array}{c}12.7 \pm 2.8 \ddagger \\
19.5 \pm 3.3 \ddagger^{*} \\
8.9,19.6\end{array}$ & $\begin{array}{c}1.4 \pm 0.3 \ddagger \\
2.7 \pm 0.7 \ddagger \\
0.7,1.6\end{array}$ & $\begin{array}{c}20 \cdot 3 \pm 8 \cdot 1 \\
14 \cdot 9 \pm 5 \cdot 3 \\
9 \cdot 5,20 \cdot 0\end{array}$ \\
\hline Sheep & 10 & $16-18$ & FT & $\mathbf{A}$ & $1.3 \pm 0.5$ & $0.3 \pm 0.2$ & $0.3 \pm 0.2$ & $4 \cdot 6 \pm 1 \cdot 0$ \\
\hline Cow & $\begin{array}{l}2 \\
1 \\
4 \\
3\end{array}$ & $\begin{array}{c}16,22 \\
21 \\
28-33 \\
41-44 \\
\\
60-65\end{array}$ & $\begin{array}{c}\text { FT } \\
\text { FT } \\
\text { CS } \\
\text { ACT } \\
\text { loosely } \\
\text { attached } \\
\text { AC }\end{array}$ & $\begin{array}{c}\text { A } \\
\text { DHA } \\
\text { A } \\
\mathbf{A}\end{array}$ & $\begin{array}{c}1 \cdot 1,1.4 \\
4.1 \\
0.7 \pm 0.1 \\
1 \cdot 1 \pm 0.5\end{array}$ & $\begin{array}{c}1.8,1.8 \S \\
3.8 \S \\
0.1 \S \\
0.03 \S\end{array}$ & $\begin{array}{c}0.1,0.2 \S \\
2.0 \S \\
0.01 \S \\
0.01 \S\end{array}$ & $\begin{array}{c}4.8,5.4 \\
5 \cdot 1 \\
3.9 \pm 0.7 \\
4.2 \pm 0.6 \\
9.6 \pm 2.0\end{array}$ \\
\hline \multirow[t]{3}{*}{ Roe deer } & 2 & January & $\begin{array}{l}4 \text { B (not } \\
\text { elongated) }\end{array}$ & A & $0.3,0.3$ & $<0.1,0.5$ & $<0 \cdot 1,<0 \cdot 1$ & $1 \cdot 5,14 \cdot 3$ \\
\hline & 1 & January & $\begin{array}{c}\text { ACI } \\
\text { (attached) }\end{array}$ & A & 3.7 & $2 \cdot 3 \ddagger$ & $0 \cdot 1$ & $21 \cdot 7$ \\
\hline & 1 & January & $\begin{array}{l}\text { AC (not } 9 \\
\text { attached) }\end{array}$ & A & $2 \cdot 7$ & $1.4 \ddagger$ & 0.1 & 34.5 \\
\hline Ferret & $\begin{array}{l}1 \\
1\end{array}$ & $\begin{array}{l}13 \\
15\end{array}$ & $\begin{array}{c}8 \mathrm{IST} \\
14 \mathrm{ISq} \\
(650 \mathrm{mg})\end{array}$ & $\begin{array}{l}\text { DHA } \\
\text { DHA }\end{array}$ & $\begin{array}{l}2 \cdot 6 \\
3 \cdot 1\end{array}$ & $\begin{array}{l}0.2 \\
0.3\end{array}$ & $\begin{array}{l}0.2 \\
0.2\end{array}$ & $\begin{array}{l}25 \cdot 0 \\
10 \cdot 0\end{array}$ \\
\hline Cat & $\begin{array}{l}1 \\
1\end{array}$ & $\begin{array}{l}11 \\
13\end{array}$ & $\begin{array}{l}5 \mathrm{~B} \| \\
5 \mathrm{IS} ף\end{array}$ & $\begin{array}{l}\text { DHA } \\
\text { DHA }\end{array}$ & $\begin{array}{l}1.7 \\
5 \cdot 3\end{array}$ & $\begin{array}{l}0.4 \\
1.0\end{array}$ & $\begin{array}{l}0.5 \\
1.0\end{array}$ & $\begin{array}{r}10 \cdot 1 \\
5 \cdot 0\end{array}$ \\
\hline Rabbit & 3 & 6 & $\begin{array}{c}30 \mathrm{~B} \\
(60 \mathrm{mg})\end{array}$ & DHA & $1 \cdot 1$ & 0.2 & $0 \cdot 2$ & $2 \cdot 0$ \\
\hline Plains viscacha & 1 & 18 & $100 \mathrm{~B}$ & DHA & 0.5 & $<0 \cdot 1$ & $<0.1$ & 2.9 \\
\hline
\end{tabular}

Tissue (approx. $300 \mathrm{mg}$ wet weight except as stated) was incubated for $3 \mathrm{~h}$ at $37^{\circ} \mathrm{C}$ with $\left[{ }^{3} \mathrm{H}\right]$ androstenedione (A), $\left[{ }^{3} \mathrm{H}\right]$ dehydroepiandrosterone (DHA) or $\left[{ }^{3} \mathrm{H}\right]$ testosterone $(\mathrm{T})$, and the amount of radioactivity incorporated into phenolic and aqueous-soluble (conjugated) steroids, and into oestrone and oestradiol-17ß was determined. Values are means \pm s.e.m. or the average of duplicate incubations.

* Difference statistically significant compared with A; Student's $t$ test, $P<0.03$.

$\dagger$ No. of determinations.

** FT, filamentous trophoblast; CS, chorionic sac; AC, allantochorion; B, blastocysts; IS, implantation sites.

$\ddagger$ Identified by recrystallization to constant specific radioactivity.

$\S$ Eluates of areas of thin-layer chromatographs corresponding to authentic steroids were pooled and identified by recrystallization to constant specific radioactivity (16-65 days p.c.). Tissue wet weight $1 \mathrm{~g}$ for one animal in each group, $28-65$ days.

\| Tissue wet weight not determined.

Material obtained after implantation; in roe deer embryo crown-rump length, $26 \mathrm{~mm}$; embryo weights, 1.5 and $1.6 \mathrm{~g}$. 


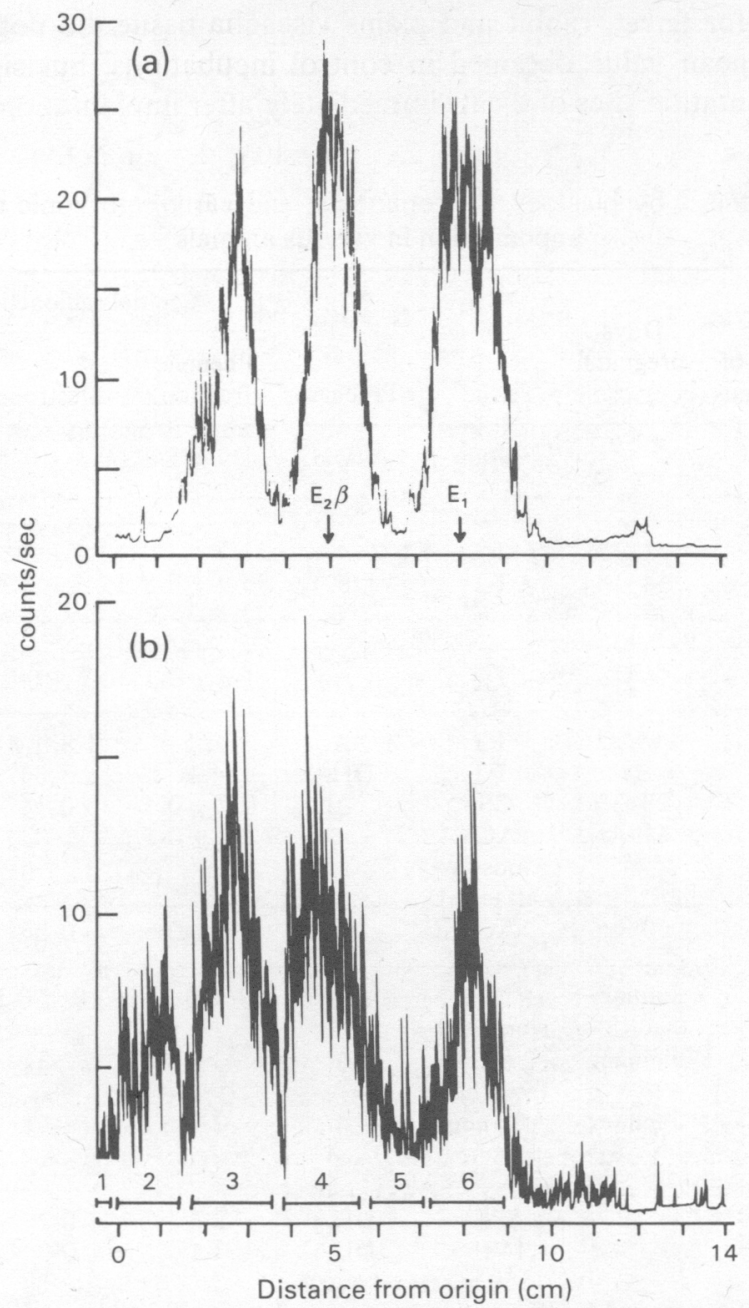

Text-fig. 1. Radiochromatogram scans showing the pattern of metabolism of $(a)\left[{ }^{3} \mathrm{H}\right]$ oestrone or (b) [ $\left.{ }^{3} \mathrm{H}\right]$ androstenedione by 16-day blastocyst tissue of the pig. After incubation of tissue (approx. $300 \mathrm{mg}$ wet weight) by the procedure described in the text, phenolic and neutral steroid fractions were prepared from incubations (a) and (b), respectively. The phenolic fraction from incubation with $\left[{ }^{3} \mathrm{H}\right]$ oestrone (a) was applied to a thin-layer chromatograph plate, and, together with authentic oestrone $\left(E_{1}\right)$ and oestradiol-17 $\left(E_{2} \beta\right)$ in parallel lanes, developed in the solvent system, benzene:methanol, 9:1 (v/v). The neutral fraction from incubation with $\left[{ }^{3} \mathrm{H}\right]$ androstenedione (b) was chromatographed in the same solvent system. Regions of the plate numbered 1 to 6 were eluted and radioactivity was counted; authentic androstenedione was recovered from region 6, dehydroepiandrosterone and androsterone from region 5, and testosterone from region 4.

In all experiments labelled $\mathrm{C}-19$ precursors were converted into aqueous soluble compounds, the highest values being found in trophoblast incubations from pigs, roe deer, ferrets and cats (Table 1).

\section{Neutral steroid metabolites}

In view of the contrast in trophoblast aromatase activity of the pig, sheep and cow, the pattern of androstenedione metabolism was also examinedi(Table 2 2) ) Labelled androstenedione $8: 39: 46 \mathrm{AM}$ 
(or DHA) was incubated for $3 \mathrm{~h}$ with trophoblast tissue and the neutral steroid metabolites were extracted and chromatographed on thin-layer chromatograph plates. The neutral steroid fraction represented about $40 \%$ in pigs and $90-95 \%$ in sheep and cows of the total substrate radioactivity added. In pigs $<11 \%$ of the neutral steroid radioactivity was associated with unmetabolized substrate; values in cows and sheep were 6 and 1\%, respectively. Trophoblast produced a number of metabolites more polar than androstenedione and in pigs they were found in 4 major bands of radioactivity (Text-fig. 1b) compared with 3 in cows and 2 in sheep (Table 2). Labelled DHA was also extensively metabolized in pigs, $10 \%$ of the neutral steroid radioactivity being chromatographically similar to andostenedione.

Table 2. Metabolism of $\left[{ }^{3} \mathrm{H}\right]$ androstenedione (A) and $\left[{ }^{3} \mathrm{H}\right]$ dehydroepiandrosterone (DHA) by early embryonic tissues in pigs, cows and sheep

\begin{tabular}{|c|c|c|c|c|c|c|c|c|c|c|}
\hline \multirow[b]{2}{*}{ Species } & \multirow{2}{*}{$\begin{array}{l}\text { No. of } \\
\text { animals }\end{array}$} & \multirow{2}{*}{$\begin{array}{c}\text { Days } \\
\text { pregnant } \\
\text { p.c. }\end{array}$} & \multirow{2}{*}{$\begin{array}{l}\text { Pre- } \\
\text { cursor }\end{array}$} & \multirow[b]{2}{*}{ Tissue* } & \multicolumn{6}{|c|}{$\%$ radioactivity associated with: } \\
\hline & & & & & 1 & 2 & 3 & 4 & 5 & 6 \\
\hline Pig & 3 & 16 & $\underset{\text { DHA }}{\text { A }}$ & $\begin{array}{l}\text { FT } \\
\text { FT }\end{array}$ & $\begin{array}{l}12.6 \\
31.7\end{array}$ & $\begin{array}{c}21 \cdot 3 \pm 5.7 \\
<1 \cdot 0\end{array}$ & $\begin{array}{c}41 \cdot 0 \pm 6 \cdot 0 \\
22 \cdot 9\end{array}$ & $\begin{array}{c}18 \cdot 5 \pm 5 \cdot 8 \\
10 \cdot 7\end{array}$ & $\begin{array}{l}<1.0 \\
18.0\end{array}$ & $\begin{array}{c}10 \cdot 7 \pm 1.8 \\
10 \cdot 1\end{array}$ \\
\hline Cow & $\begin{array}{l}2 \\
1 \\
2\end{array}$ & $\begin{array}{l}29 \\
42 \\
60\end{array}$ & $\begin{array}{l}\text { A } \\
\text { A } \\
\text { A }\end{array}$ & $\begin{array}{l}\mathrm{CS} \\
\mathrm{AC} \\
\mathrm{AC}\end{array}$ & $\begin{array}{l}<1.0 \\
<1.0 \\
<1.0\end{array}$ & $\begin{array}{l}<1.0 \\
<1.0 \\
<1.0\end{array}$ & $\begin{array}{r}60.0 \\
79.5 \\
<1.0\end{array}$ & $\begin{array}{l}40.0 \\
<1.0 \\
89.5\end{array}$ & $\begin{array}{l}<1.0 \\
20.5 \\
10.5\end{array}$ & $\begin{array}{l}<1.0 \\
<1.0 \\
<1.0\end{array}$ \\
\hline Sheep & 7 & $14-18$ & $\mathbf{A}$ & FT & $<1.0$ & $<1.0$ & $66.9 \pm 1.9$ & $<1.0$ & $26 \cdot 8 \pm 2 \cdot 7$ & $5 \cdot 5 \pm 1 \cdot 7$ \\
\hline
\end{tabular}

Labelled substrate was incubated with approx. $300 \mathrm{mg}$ tissue for $3 \mathrm{~h}$ at $37^{\circ} \mathrm{C}$; neutral steroids were recovered by thin-layer chromatography. Values (means \pm s.e.m. where appropriate) represent radioactivity associated with 6 regions of the chromatogram (1-6) expressed as a percentage of the neutral steroid fraction radioactivity. A value of $<1.0 \%$ indicates results indistinguishable from background.

Chromatographic mobility was expressed as $R_{\mathrm{s}(\text { and.) }}=$ distance from origin of unknown steroid/distance from origin of androstenedione. The $R_{\text {s(and.) }}$ values were: 1 , origin; $2,0.06-0.22 ; 3,0.25-0.46 ; 4,0.49-0.68 ; 5$, $0.72-0.87 ; 6,0.88-1.07$ (see Text-fig. 1). Chromatographic mobility of androstenedione was associated with region 6; dehydroepiandrosterone and androsterone with region 5; and testosterone with region 4.

* FT, filamentous trophoblast; CS, chorionic sac; AC, allantochorion.

\section{Discussion}

Oestrogen synthesis by early embryonic tissue was appreciably higher in the pig than in the 7 other species investigated. Definitive evidence for oestrogen synthesis by preimplantation trophoblast was obtained in the pig with the isolation of 3 naturally occurring oestrogens, oestrone, oestradiol-17 $\beta$ and oestradiol-17 $\alpha$, and the detection of a more polar oestrogen resembling oestriol in its chromatographic properties. Oestrogen synthesis was also demonstrated in the cow (oestrone and oestradiol-17ß) and roe deer (oestrone), although only with extracts from incubations which included allantochorionic tissue recovered during attachment and implantation. However, the highest values for aromatase activity in the cow were found in tissue taken between Days 16 and 22 p.c. This corresponds with the time when uterine blood flow to the gravid horn increases significantly compared with that to the non-gravid horn (Ford, Chenault \& Echternkamp, 1979), mimicking the vasodilatatory effects of oestrogen reported for cows and other mammals (Roman-Ponce, Thatcher, Caton, Barron \& Wilcox, 1978; Huckabee, Crenshaw, Curet, Mann \& Barron, 1970). Apart from the above examples, aromatase activity in early trophoblast was not detectable although this may reflect a lack of sensitivity of the method rather than an absolute deficiency in enzyme activity. An exception was found in tissue recovered from the implantation sites of cats immediately after implantation. However, the tissue examined consisted of embryonic and maternal components and the possibility of uterine

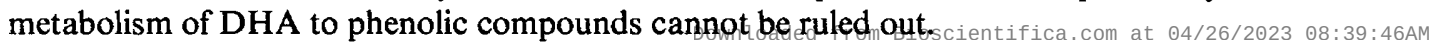


The findings raise the question of why aromatase activity should be so high in preimplantation trophoblast tissue in the pig compared with the other animals examined. A possible role of blastocyst oestrogen synthesis is to provide an embryonic signal for the maternal recognition of pregnancy which results in prolongation of the life-span and function of the corpus luteum. In the pig, oestrogen is luteotrophic, causes the life-span of corpora lutea to be extended, and increases progesterone content of luteal tissue (Kidder, Casida \& Grummer, 1955; Gardner, First \& Casida, 1963; Frank, Bazer, Thatcher \& Wilcox, 1977). It has been proposed that a mechanism by which blastocyst oestrogen production may prolong luteal function in early pregnancy may involve a redirection of uterine prostaglandin (PG) secretion away from uterine venous blood towards the uterine lumen, thereby protecting the corpus luteum from the luteolytic effect of PGF-2 $\alpha$ (Bazer \& Thatcher, 1977). In the cow, maternal recognition of pregnancy occurs about Day 16 (Betteridge, Eaglesome, Randall, Mitchell \& Sugden, 1978) and this coincides with the formation of oestradiol-17 $\beta$ from labelled androstenedione by some conceptuses, beginning on Day 15 (Eley, Thatcher, Bazer \& Fields, 1979), and with the local increase in uterine blood flow (Ford et al., 1979) referred to previously. However, high doses of oestrogen (including oestrone sulphate) administered systemically are luteolytic in the cow (Eley, Thatcher \& Bazer, 1979), so that, if oestrogen is active in this way, it presumably acts as a short-range rather than a systemic signal to induce a local endometrial effect. The absence of aromatase from sheep trophoblast between Days 16 and 18 p.c. is difficult to reconcile with the above interpretation, except that the results of Greiss \& Anderson (1970) also suggest an increase in uterine blood flow to the gravid horn during the preimplantation period consistent with uterine vasodilatation associated with local oestrogen administration (Greiss \& Miller, 1971). Maternal recognition of pregnancy in the sheep occurs about Day 12 p.c. and this is a time when the amount of trophoblast tissue available is too meagre to permit detection of aromatase activity by the present technique.

The report by Zavy, Mayer, Vernon, Bazer \& Sharp (1979) indicates that oestrogen production by preimplantation trophoblast is also considerable in the mare. Tissue incubated in vitro for $90 \mathrm{~min}$ produced up to $20 \mathrm{ng}$ oestrone and $100 \mathrm{ng}$ oestradiol per $5 \mathrm{ml}$ culture medium. Oestrogen production rose from Day 12 to 20 p.c., encompassing the time of maternal recognition of pregnancy which in this species occurs at about Day 16 p.c. (see Allen, 1979). These findings resemble those obtained for the sow, although it is uncertain whether trophoblast oestrogens act in a similar way since there is controversy about whether exogenous oestrogens are luteolytic in the mare (Allen, 1979), or luteotrophic (Berg \& Ginther, 1978) as in the sow. The association of superficial implantation and pronounced aromatase activity in the preimplantation trophoblast of sows and mares raises the possibility that these events are related; however, in the mare endometrial invasion by highly specialized trophoblast cells occurs between Days 36 and 38 p.c. to form endometrial cups (Allen, 1979). No parallel event occurs in the pig.

The occurrence of aromatase in the allantochorionic placenta of the roe deer is consistent with the increase in plasma unconjugated oestrogens that occurs with embryo activation and implantation and supports the suggestion of Aitken (1974) that the circulating hormone originates from the conceptus rather than the ovarian follicles. No physiological role has been described for this placental oestrogen production. The absence of aromatase from rabbit blastocysts on Day 6 agrees with the findings of George \& Wilson (1978) who showed that it increased significantly only on the day of implantation (Day $6 \frac{1}{2}-7$ ) and reached a maximum on Day 8. The apparent absence of aromatase, however, does not mean that blastocysts or early embryonic tissues are devoid of steroid-metabolizing activity (Singh \& Booth, 1979). The conversion of androstenedione to oestrogens was low or undetectable in cows and sheep, respectively, but androstenedione was metabolized extensively to other neutral steroids. Cow blastocysts obtained between Days 13 and 16 p.c. produced progesterone, testosterone and prostaglandins in culture (Shemesh, Milaguir, Ayalon \& Hansel, 1979) and contained bovine 
placental lactogen (Flint, Henville \& Christie, 1979). These observations provide further evidence for the idea that preimplantation trophoblast possesses diverse endocrine properties.

In summary, a high activity of aromatase found in preimplantation trophoblast of pigs was not a consistent feature among those animals (cows and sheep) in which the maternal recognition of pregnancy occurs before definitive implantation. However, the similarity between our findings for pigs and those reported for mares suggests that trophoblast oestrogen synthesis may be associated with superficial implantation.

We thank Dr J. S. Perry for help and advice during this project; Dr A. P. F. Flint and Dr T. Wise for comments on the paper; and Professor E. C. Amoroso, Mr L. E. A. Rowson, Mr R. W. Ash, $\cdot \mathrm{Mr} \mathrm{J}$. Smith and Mr D. Twiddy of this Institute, the late Dr R. Gibbons of the Institute for Research in Animal Diseases, Newbury, Mr J. Hammond, Jr, Department of Applied Biology, Cambridge, and Dr B. J. Weir, Cambridge, for animals. J.E.G. received financial support from the Agricultural Research Council, the Royal College of Veterinary Surgeons Trust Fund and the Meat and Livestock Commission.

\section{References}

Aitken, R.J. (1974) Delayed implantation in roe deer (Capreolus capreolus). J. Reprod. Fert. 39, 225-233.

Allen, W.R. (1979) Maternal recognition of pregnancy and immunological implications of trophoblast-endometrium interactions in equids. In Maternal Recognition of Pregnancy (Ciba Fdn Symp. N.S. 64), pp. 323-346. Ed. J. Whelan. Excerpta Medica, Amsterdam.

Anderson, L.L. (1978) Growth, protein content and distribution of early pig embryos. Anat. Rec. 190, 143-154.

Bazer, F.W. \& Thatcher, W.W. (1977) Theory of maternal recognition of pregnancy in swine based on estrogen controlled endocrine versus exocrine secretion of prostaglandin $\mathrm{F}_{2 a}$ by the uterine endometrium. Prostaglandins 14, 397-401.

Berg, S.L. \& Ginther, O.J. (1978) Effect of estrogens on uterine tone and life span of the corpus luteum in mares. J. Anim. Sci. 47, 203-208.

Betteridge, K.J., Eaglesome, M.D., Randall, G.C.B., Mitchell, D. \& Sugden, E.A. (1978) Maternal progesterone levels as evidence of luteotrophic or antiluteolytic effects of embryos transferred to heifers 12-17 days after estrus. Theriogenology 9, 86, Abstr.

Brinster, R.L. (1965) Studies on the development of mouse embryos in vitro. IV. Interaction of energy sources. J. Reprod. Fert. 10, 227-240.

Challis, J.R.G., Harrison, F.A. \& Heap, R.B. (1973) The metabolic clearance rate, production rate and conversion ratios of oestrone in the sheep. $J$. Endocr. $58,435-446$.

Dhindsa, D.S. \& Dziuk, P.J. (1968) Effect of pregnancy in the pig after killing embryos or fetuses in one uterine horn in early gestation. J. Anim. Sci. 27, 122-126.

Dickmann, Z., Dey, S.K. \& Sen Gupta, J (1976) A new concept: control of early pregnancy by steroid hormones originating in the preimplantation embryo. Vitams Horm. 34, 215-242.

Eley, R.M., Thatcher, W.W. \& Bazer, F.W. (1979) Luteolytic effect of oestrone sulphate on cyclic beef heifers. J. Reprod. Fert. 55, 191-193.
Eley, R.M., Thatcher, W.W., Bazer, F.W. \& Fields, M.J. (1979) Metabolism of progesterone and androstenedione in vitro by bovine endometrium and conceptus. J. Anim. Sci. 149, 294 A.

Flint, A.P.F., Henville, A. \& Christie, W.B. (1979) Presence of placental lactogen in bovine conceptuses before attachment. J. Reprod. Fert. 56, 305-308.

Flint, A.P.F., Burton, R.D., Gadsby, J.E., Saunders, P.T.K. \& Heap, R.B. (1979) Blastocyst oestrogen synthesis and the maternal recognition of pregnancy. In Maternal Recognition of Pregnancy (Ciba Fdn Symp. N.S. 64), pp. 209-228. Ed. J. Whelan. Excerpta Medica, Amsterdam.

Ford, S.P., Chenault, J.R. \& Echternkamp, S.E. (1979) Uterine blood flow of cows during the oestrous cycle and early pregnancy: effect of the conceptus on uterine blood supply. J. Reprod. Fert. 56, 53-62.

Frank, M., Bazer, F.W., Thatcher, W.W. \& Wilcox, C.J. (1977) A study of prostaglandin $F_{2 \alpha}$ as the luteolysin in swine. III. Effects of estradiol valerate on prostaglandin $F$, progestins, estrone and estradiol concentration in the utero-ovarian vein of nonpregnant gilts. Prostaglandins 14, 1183-1196.

Gadsby, J.E, Burton, R.D., Heap, R.B. \& Perry, J.S. (1976) Steroid metabolism and synthesis in early embryonic tissue of the pig, sheep and cow. $J$. Endocr. 71, 45-46P.

Gardner, M.L., First, N.L. \& Casida, L.E. (1963) Effect of exogenous estrogens on corpus luteum maintenance in gilts. J. Anim. Sci. 22, 132-134.

George, F.W. \& Wilson, J.D. (1978) Estrogen formation in the early rabbit embryo. Science, N.Y. 199, 200-201.

Greiss, F.C., Jr \& Anderson, S.G. (1970) Uterine blood flow during early ovine pregnancy. Am. J. Obstet. Gynec. 106, 30-38.

Greiss, F.C., Jr \& Miller, H.B. (1971) Unilateral control of uterine blood flow in the ewe. Am. J. Obstet. Gynec. 111, 299-301.

Huckabee, W.E., Crenshaw, C., Curet, L.B., Mann, L. \& Barron, D.H. (1970) The effect of exogenous oestrogen on the blood flow and oxygen consumption of the uterus of the nonpregnant ewe. $Q$. $J l \exp$. Physiol. 55, 16-24. 
Kidder, H.E., Casida, L.E. \& Grummer, R.H. (1955) Some effects of estrogen injections on the estrual cycle of gilts. J. Anim. Sci. 14, 470-474.

Perry, J.S., Heap, R.B. \& Amoroso, E.C. (1973) Steroid hormone production by pig blastocysts. Nature, Lond. 245, 45-47.

Perry, J.S., Heap, R.B., Burton, R.D. \& Gadsby, J.E. (1976) Endocrinology of the blastocyst and its role in the establishment of pregnancy. $J$. Reprod. Fert., Suppl. 25, 85-104.

Ricketts, A.P., Galil, A.K.A., Ackland, N., Heap, R.B. \& Flint, A.P.F. (1980) Activation by corticosteroids of steroid metabolizing enzymes in ovine placenta explants in vitro. J. Endocr. 85, 457-469.

Roman-Ponce, H., Thatcher, W.W., Caton, D., Barron,
D.H. \& Wilcox, C.J. (1978) Thermal stress effects on uterine blood flow in dairy cows. J. Anim. Sci. 46, 175-180.

Shemesh, M., Milaguir, F., Ayalon, N. \& Hansel, W. (1979) Steroidogenesis and prostaglandin synthesis by cultured bovine blastocysts. J. Reprod. Fert. 56, 181-185.

Singh, M.M. \& Booth, W.D. (1979) Origin of oestrogen in preimplantation rabbit blastocysts. J. Steroid Biochem. 11, 723-728.

Zavy, M.T., Mayer, R., Vernon, M.W., Bazer, F.W. \& Sharp, D.C. (1979) An investigation of the uterine luminal environment of non-pregnant and pregnant Pony mares. J. Reprod. Fert., Suppl. 27, 403-411.

Received 17 March 1980 